\title{
Trends and Determinants of Output Growth Volatility in South Africa
}

\author{
Fatima Bhoola \\ Lecturer, School of Economic and Business Sciences, University of Witwatersrand \\ Johannesburg, South Africa
}

Dr. Uma Kollamparambil (Corresponding author)

Associate Professor, School of Economic and Business Sciences, University of Witwatersrand

Johannesburg, South Africa

Tel: 27-11-717-8113 E-mail: uma.kollamparambil@wits.ac.za

Received: March 23, 2011

Accepted: April 20, 2011

doi:10.5539/ijef.v3n5p151

\begin{abstract}
Notwithstanding the recent financial crisis, many industrial countries have experienced a significant decline in macroeconomic volatility characterised by less volatile output growth over the last three decades. Literature refers to this decline as the 'great moderation and though there is no consensus on the possible cause, scholars consistently attribute it to three main factors: Improvements in macroeconomic policy, implementation of better inventory management and to the so called 'good luck' hypothesis. The aim of this paper is to observe the trends and determinants of output growth volatility in South Africa. The study indicates that South Africa experienced a significant structural break in the early 1990s in output growth. Further investigation, into the possible causes, reveals that monetary policy contributed significantly to the falling volatility of output growth.
\end{abstract}

Keywords: Output Growth volatility, Quandt-Andrews unknown breakpoint test, ARDL bounds testing approach

\section{Introduction}

Prior to the recent global economic crisis, a substantial amount of literature revealed that output volatility in industrial countries had considerably declined over the last three decades. This phenomenon dubbed the 'great moderation' by Stock and Watson (2002) has invariably been used to describe the macroeconomic environment characterised by the decline in both inflation and output volatility that countries such as the United States (McConnell and Perez-Quiros, 2000; Kahn et al, 2001) and other industrial countries (Mills and Wang, 2000; Blanchard and Simon, 2001; Smith and Summers, 2002) have come to experience in recent decades especially the 1990's.

Although there exists some evidence to suggest that the great moderation has extended to emerging and developing countries such that the volatility of growth and the severity of the output drops have declined, levels of output volatility still remain substantially higher than industrial countries (Cecchetti et al, 2006; Hakura ,2007, Agenor et al 1999). South Africa experienced a similar moderation characterized by lower and stable inflation, lower and stable real interest rates, positive and steady GDP growth and stable fiscal deficits and debt (Du Plesis and Kotze, 2010; Aron and Muellbauer, 2008; Du Plessis et al. 2007 and; Burger, 2008). These studies however, do not focus on determining the breakpoints of volatility concentrating rather in measuring volatility in different periods segregated according to the political environment of the country. Du Plessis (2006) is an exception in this regard and uses the time-varying stochastic volatility models to identify the structural breaks using data from 1960Q1-2009Q3 although the study does not proceed to identify the determinants behind the declining volatility.

The contribution of our study is to estimate volatility and search for structural breaks for the period 1970Q1-2010Q4 employing an approach pioneered by McConnell and Perez Qurios (2000). Another point of departure in this study is that it utilises the bounds testing or ARDL model estimation approach developed by Pesaran, Shin and Smith (2001) in order to test the efficacy of stabilization policies. We are able to include larger number of policy variables because of the advantages of ARDL methodology as compared to the Vector Autoregression (VAR) model used by Burger (2008).

The rest of the paper proceeds as follows. In section 2, we estimate output growth volatility and subsequently investigate the possible structural breaks. Section 3 presents an empirical examination into the long term dynamic relationship between growth volatility and a number of possible determinants of output volatility. This is followed by a brief conclusion. 


\section{The Changing Nature of Output Volatility in South Africa}

\section{Estimating output volatility}

In this section we aim to establish trends of output volatility in South Africa with quarterly data over the period 1970-2010 using a methodology pioneered by McConnell and Perez-Quiros (2000). The analysis is undertaken in a series of steps. Firstly, we characterise quarterly output growth as an AR model of the following form:

$$
\Delta \mathrm{y}_{\mathrm{t}}=\mu+\rho \Delta \mathrm{y}_{\mathrm{t}-1}+\varepsilon_{\mathrm{t}},
$$

Where $\Delta y$ is the first difference of GDP growth, $\rho$ represents the persistence of output growth and $\varepsilon$ is an error term that is independent over time but not necessarily identically distributed as stated in Cechetti et al (2006). Given that the initial AR (1) model remains plagued by serial correlation in the error term, we account for the correlation by using Newey-West standard errors and by including an additional lag of the dependant variable. The results of estimating this AR (2) specification, is a series of estimated residuals $\varepsilon_{t}$. McConnell and Perez Quiros, (2000) who pioneered the technique argue that, provided these residuals are normally distributed, the transformed residuals, specified as the root mean squared error or $\sqrt{ } \Pi / 2\left|\varepsilon_{t}\right|$, are unbiased estimators of the standard deviation of $\varepsilon_{t}$. Using these, we proceed to the second stage which involves searching for structural breaks in the mean or constant of the following volatility equation:

$$
\sqrt{ } \Pi / 2|\varepsilon \tau|=\alpha+\mu \tau
$$

Where, the volatility is captured as the deviation of the quarterly growth rate from a trend generated by the Hodrick-Prescott (HP) filter. We utilise an optimal HP filter for South Africa constructed by Du Toit (2008). It differs from the original de-trending method in that, instead of using the default lambda or smoothing constant initially suggested by Hodrick and Prescott (1980), which is ad hoc and often has problematic underlying assumptions, Du Toit (2008) develops an optimal smoothing constant which least distorts the frequency information of the time series by taking into account both the duration of the business cycle as well as the structure of the economy. According to Pretorius and Venter (2001) and; Pretorius, Venter and Wiedeman (1999) the duration of South Africa's business cycle has, on average, been 4.79 years since 1960. Thus when using quarterly data, optimal HP filtering for South Africa is best implemented with a value of 352 for lambda.

In searching for structural breaks, the study applies the Quandt-Andrews unknown breakpoint test as derived in Andrews (1993). This test was chosen since it allows for multiple breaks. This according to Bai (1997), Bai and Perron (2003) and others, is superior to tests for single breaks since these typically have low power in the presence of multiple breaks and, as mentioned earlier, may be invalid due to the variances not being constant. The test essentially involves the joint estimation of equation 1 and 2 by General Method of Moments (GMM) over the entire sample period. If the test statistic associated with a potential break date is significant, the equation is re-estimated by trimming the data set but still retaining the potential break date that was significant. This is done by adding dummy variables to equation 2 , which allows the constant to equal $\alpha 1$ if is less than $T$, and $\alpha 2$ otherwise. If once again the same break date is significant, the data set is automatically trimmed again so that the period is smaller but still contains the break date identified.

If Fn (T) is the computed LR, or Wald F-Statistic test for the equality of coefficients $\alpha 1$ and $\alpha 2$ under the null hypothesis of no break, then quite intuitively, it follows that the period $\mathrm{T}$ in which $\mathrm{Fn}(\mathrm{T})$ takes on the highest value is the most probable break date. Consequently, Andrews (1993) provides the following statistic:

$$
\sup F n=\sup _{T 1 \leq T \leq T 2} F n(T)
$$

Such that the T that maximises Fn(T), is the significant break date. A later study by Andrews and Ploberger (1994) refute the above statistic on the basis that it is not optimal and subsequently propose the two alternative statistics listed below, whose $\mathrm{p}$-values are computed using the technique applied by Hansen (1997).

$\exp \mathrm{Fn}=\ln \left(1 / \mathrm{T} 2-\mathrm{T} 1+1 * \sum_{T=T 1}^{T 2} \exp (1 / 2 * F n(T)) \quad\right.$ and $\quad$ ave $\mathrm{Fn}=1 / \mathrm{T} 2-\mathrm{T} 1+1 * \sum_{T=T 1}^{T 2} F n(T)$

Table 1 reports the significant break dates based on the LR statistic test for structural breaks in the AR coefficient and the residual variance to be 1991Q3.

Following Ramey and Ramey (1995) we test the robustness of the results obtained using the "McConell and Perez-Quiros (2000) technique", using the more widely applied measure of the standard deviation. For this purpose we divide the sample to two sub periods viz., 1970Q2-1991Q3 and 1991Q4-2010Q3 based on the Quandt-Andrews unknown breakpoint test. It is quite evident that the volatility of real GDP as well as the volatility of its components, with the exception of imports, has substantially declined from the first to the second period (Table2). 


\subsection{Determinants of the Change in Output Volatility}

In light of the lack of consensus on the causes of the 'great moderation' a burgeoning volume of literature dedicated to explaining the possible reasons emerged. These factors fall into three broad categories, the first is changes in economic policy, more specifically, the efficacy of monetary and fiscal policies as suggested in (Boivin and Giannoni, 2006; Cecchetti et al 2006; Cecchetti and Ehrmann, 1999; Clarida and Gali, 2000; Svensson, 2000 and; Svensson and Hall, 2003). Secondly, reduced business cycle volatility has also been linked to structural reforms in markets including: changes in the labour market regulation as supported by the findings of Kent et al (2005), as well as trade openness, and liberalisation of financial markets as discussed in Easterly et al (2001), Agenor et al (1999), Kose et al (2006) and Bejan (2006). Finally, plain good luck, reflected as smaller and/or less frequent shocks has invariably been proposed by Stock and Watson (2002) and Ahmed and Levin (2004) as another possible explanation. By their nature, the first three structural factors are likely to have a more permanent effect on output volatility, while a decline in global shocks (irrespective of structural factors) may only be temporary (Gali and Gambetti, 2009).

While the studies on developed countries all concede that volatility has declined, the results for developing countries portray a rather ambiguous outcome. Hakura (2007) concludes that the fall in volatility experienced by developing countries is mainly due to less volatile country-specific factors while still leaving countries vulnerable to external shocks. Wolf (2004), Agenor, et al (2000), Easterly (2001) and; Malik and Temple (2006) highlight the varied experiences of developing countries attributing the differences to structural, institutional, and policy variations among them. Burger (2008) traces the drop in growth volatility to the reduction in the volatility of household consumption (especially durables and services), as well as a decline in the volatility of investment in the manufacturing sector and improved monetary policy by the South African Reserve Bank. In this study we focus specifically on the role that macroeconomic policy has played in mitigating output growth volatility.

\section{Empirical Analysis}

Determinants of Volatility: In this section we discuss briefly the determinants of output volatility, their expected relationship to volatility and their measurement for inclusion in the econometric model.

1 Monetary Policy Indicators: We construct two direct measures for monetary policy. The first labelled Monetary Policy Indicator or MPI is a measure aimed at capturing the stabilising effects of the monetary policy instrument while the second indicator is essentially an Inflation Targeting dummy (ITDUMMY) variable which takes on the value of 0 prior to $2000 \mathrm{Q} 1$ and 1 thereafter following South Africa adopting an inflation targeting policy. The MPI measures the extent to which interest rates deviate from stabilising monetary policy rules (Taylor, 1995; and Woodford 2001). A priori, the indicator is expected to be positively correlated with output growth volatility. This implies that a large value on the MPI is indicative of developments in real interest rates that stabilise inflation while doing little to stabilise output and will therefore be associated with higher output volatility. The indicator is formally stated as follows:

$$
\text { MPI }_{\mathrm{t}}=\left[\mathrm{ri}_{\mathrm{t}}-\left(\mathrm{ri}^{\mathrm{e}}+\alpha \times\left(\pi_{\mathrm{t}}-\pi \text { trend }_{\mathrm{t}}\right)+\beta \times\left(\operatorname{og}_{\mathrm{t}}\right)\right)\right]^{2}
$$

Where: $r i_{t}$ is the real short-term interest rate; $r i^{e}$ is the equilibrium interest rate; $o_{t}$ is the output gap; $\pi_{t}$ is the inflation rate and $\pi$ trend $d_{t}$ is the trend inflation rate (as derived from an HP filter)

A number of practical assumptions have been made in constructing this indicator. Firstly trend growth is taken as a proxy for the equilibrium real interest rate. Secondly, the output target and the inflation target are derived from an optimal HP filtering process developed by Du Toit (2008). Finally, although a number of model simulations have altered the weights on the deviation of output and inflation from their respective targets, this study sets the respective weights on the inflation and the output gap at 0.5 as originally applied by (Taylor, 1993).

2 Fiscal Policy Indicator: Structural budget balance, cyclically adjusted fiscal balance, government expenditure are some of the proxies of fiscal policy used in various studies. This study utilizes the ratio of total government expenditure to GDP as a Fiscal Policy Indicator (FPI). This is in line with Fatas and Mihov (2001) as well as Du Plessis (2006) and is based on the assumption of a close link between the size of government expenditure and the power of automatic stabilisers such that the possible role of automatic fiscal stabilisers may be captured via the average size of government expenditure as a share of GDP (Van den Noord, 2000). An effective FPI for output stabilization would therefore yield a negative sign.

3 Financial Liberalisation Indicators: The existing literature on the link between financial openness and output growth volatility approximate financial openness through a number of different variables. One such measure for the degree of financial openness is the fraction of capital flows to GDP. Net Capital Flows or (NCF) as it appears in the regression equation, has been calculated as the sum of the various foreign capital flows. The theoretical motivation for using this measure is the notion that cyclical variations in net factor income flows, as reflected in GDP, would be 
expected to capture the effects of international risk sharing on national income (Kose et al., 2006; Aghion, Bacchetta and Banerjee, 1998). On this basis, we would expect the sign on the variable to be negative. Conversely, according to the theoretical implication of the Mundell-Flemming Model as well as recent studies that have used stochastic general equilibrium models to study the effects of financial liberalisation on output volatility, higher capital flows may be associated with increased output volatility in the presence of monetary shocks. This implies that the variable NCF may also be positively related to output growth volatility.

Trade Openness Indicators: Lastly, we test trade openness using the conventional measure i.e. the sum of exports and imports as a ratio of GDP as applied by Ramey and Ramey (2000) and Bejan (2006). Increased trade in intermediate inputs through intra-industry specialisation is expected to offset any exogenous shocks and hence smooth output (Razin and Rose, 1991). Therefore the variable is expected to be negative in our model. On the Contrary, Krugman (1993) argues that if these industry-specific shocks are important determinants of the business cycle, the result could be an increase in volatility. Presumably, reliance on trade exposes the country to more external fluctuations. This is especially true in the case of emerging markets that are more vulnerable to demand, supply and terms-of- trade shocks relative to advanced nations. Based on this proposition, the sign of the coefficient on the trade liberalisation indicator may well be positive.

\section{Methodology}

The model for estimation may be written as:

$$
\sigma \mathrm{Y}_{t}=\mathrm{c}_{0}+\beta \mathrm{t}+\omega \mathrm{D}_{t+} \sum_{i=0}^{\rho} \psi i \mathrm{Z}_{t-i}+\varepsilon_{t}
$$

Where: $\sigma \mathrm{Y}_{t}$ captures volatility of output growth for various time periods, $\mathrm{c}_{0}$ represents the intercepts or drift, $\beta$ denotes a the time trend, $\mathrm{D}_{t}$ captures the inflation targeting dummy, $\mathrm{Z}_{t}=\left(\sigma \mathrm{Y}_{t}, \mathrm{MPI}_{t}, \mathrm{FPI}_{t}, \mathrm{NCF}_{t}, \mathrm{TRADEOPEN}_{t}\right)=$ $\left(\sigma \mathrm{Y}_{t}, \mathrm{X}_{t}\right)$ and finally $\varepsilon_{t}$ is the error . Given that the variables are integrated of different orders (Table 4), the use of traditional estimation procedures is rendered inapplicable. In light of this, the long run relationship between output growth volatility and the various policy indicators is established by employing the Bounds Test or Autoregressive Distributed Lag (ARDL) Model approach formulated by Pesaran Shin and Smith (2001). The advantages of this approach as opposed to other cointegration techniques are listed in Peseran and Shin (1995).

Following Pesaran et al (2001), we determine the dynamic interactions between the dependent variable and the respective explanatory variables by estimating a conditional error correction model based on equation (1). The conditional error correction model (ECM) of interest can be formally specified as:

$$
\Delta \sigma \mathrm{Y}_{t}=\mathrm{c}_{0}+\beta \mathrm{t}+\mathrm{c}_{1} \mathrm{ITDUMMY}_{t}+\pi_{\sigma \mathrm{Y} \sigma \mathrm{Y}} \sigma \mathrm{Y}_{t-1}+\pi_{\sigma \mathrm{Y} . \mathrm{X}} \mathrm{X}_{t-1}+\sum_{i=1}^{p-1} \phi \Delta \mathrm{Z}_{t-i} \delta \Delta \mathrm{X}_{t}+\varepsilon_{t}
$$

This is further expanded as:

$$
\begin{aligned}
& \Delta \sigma \mathrm{Y}_{t}=\mathrm{c}_{0}+\beta \mathrm{t}+\mathrm{c}_{1} \mathrm{ITDUMMY}_{t}+\phi_{1} \mathrm{Y}_{t-1+} \phi_{2} \mathrm{MPI}_{t-1}+\phi_{3} \mathrm{FPI}_{t-1}+\phi_{4} \mathrm{NCF}_{t-1}+\phi_{2} \text { TRADEOPEN }_{t-1}+\sum_{\mathrm{i}=1}^{p} \theta \\
& \Delta \sigma \mathrm{Y}_{t-i}+\sum_{j=1}^{q} \gamma \Delta M P I_{t-j} \quad \sum_{\mathrm{m}=1}^{q} \kappa \Delta \mathrm{FPI}_{t-m}+\sum_{\mathrm{n}=1}^{q} \lambda \Delta \mathrm{NCF}_{t-n}+\sum_{\mathrm{r}=1}^{q} \tau \quad \Delta \mathrm{TRADEOPEN}_{t-r}+\delta_{1} \Delta \mathrm{MPI}+\delta_{2} \Delta \mathrm{FPI} \\
& +\delta_{3} \Delta \mathrm{NCF}+\delta_{4} \Delta \text { TRADEOPEN }+\varepsilon_{t}
\end{aligned}
$$

Where $\phi_{\mathrm{i}}$ are the long run estimators, $\mathrm{c}_{0}$ is the drift and $\varepsilon_{t}$ are the white noise errors.

The technique begins by estimating equation (3) using OLS. The long-run relationship between the variables is established by conducting an F-Test which jointly tests the significance of the coefficients on the lagged variables. The test which is normalized on $\sigma y$ is defined as Foy:( $\sigma \mathrm{y} \mid$ MPI, FPI,NCF,TRADEOPEN). Once cointegration is confirmed based on the F statistics (Pesaran et al 2001), the second stage of the procedure involves estimating the long run estimates of the output volatility equation. The conditional ARDL (p1,q1,q2,q3,q4,) describing the long rum model can be specified as follows:

$$
\begin{gathered}
\sigma \mathrm{Y}_{\mathrm{t}}=\mathrm{c}_{0}+\beta \mathrm{t}+\mathrm{c}_{1} \text { ITDUMMY }_{t}+\sum_{i=0}^{p} \theta \sigma \mathrm{Y}_{t-1}+\sum_{i=0}^{q 1} \delta 2 \mathrm{MPI}_{t-1}+\sum_{i=0}^{q 2} \delta 3 \mathrm{FPI}_{t-1}+\sum_{i=0}^{q 3} \delta 4 \mathrm{NCF}_{t-1}+ \\
\sum_{i=o}^{q 4} \delta 6 \mathrm{TRADOPEN}_{t-1}+\varepsilon_{t}
\end{gathered}
$$

Where the variable are as those previously defined. The actual lag order of the model is selected using the Akaike (AIC) and Schwarz Bayesian (SBC) information criteria. Finally the error correction models associated with the long run estimates are obtained for which the estimated parameters describe the short run dynamics between the variables. This model is specified as follows:

$$
\begin{gathered}
\Delta \sigma \mathrm{Yt}=\mathrm{c}_{0}+\beta \mathrm{t}+\mathrm{c}_{1} \operatorname{ITDUMMY}_{t}+\sum_{i=1}^{p} \Phi \Delta \sigma \mathrm{Y}_{t-1}+\sum_{j=1}^{q 1} \varpi \Delta \mathrm{MPI}_{t-1}+\sum_{m=1}^{q 2} \eta \Delta \mathrm{FPI}_{t-1}+\sum_{n=1}^{q 3} \varphi \Delta \mathrm{NCF}_{t-1}+ \\
\sum_{r=1}^{q 4} \xi \Delta \operatorname{TRADEOPEN}_{t-1}+\operatorname{Tecm}_{t-1}+\varepsilon_{t}
\end{gathered}
$$

Results 
As suggested by Pesaran et al, (2001), we estimate the model under two cases: containing neither an intercept nor a deterministic trend and containing both the intercept as well as an unrestricted time trend. Due to space constraint we present the results of only the latter. Since some of the variables namely, the FPI i.e. the ratio of government balance to GDP is consistently insignificant in both models, we re-estimate the model while omitting this variable. Table 6 presents the Akaike (AIC) and Schwarz Bayesian (SBC) information criteria for selecting the appropriate lag lengths. In addition, the Lagrange Multiplier statistic testing the hypothesis of no residual serial correlation against orders of 1 and 4 , denoted $\chi 2 \operatorname{se}(1)$ and $\chi 2 \operatorname{sc}(4)$ respectively, is also reported.

We choose lag-length 3 based on AIC and Breusch-Godfrey test for Serial Correlation. Having chosen the lag length, the model is estimated with output volatility as the dependent variable. The Computed F-Statistic Foy $(\sigma y \mid$ MPI,FPI,NCF,TRADE $)=21.66200$ exceeds the upper bound critical value of 6.36 at the $1 \%$ significance interval.indicating that the null hypothesis of no co-integration can be rejected.

Having established the presence of cointegration between output volatility and the policy indicators, the next stage of the procedure involves estimating the long run model in the levels of the variables. Following the approach discussed by Pesaran and Shin (1995), the appropriate estimation order for the five variables was selected across a number of ARDL Models using the AIC criterion. This resulted in a choice of an ARDL $(3,3,0,0,1)$ specification. This model was estimated by ordinary least squares. To account for the possibility of heteroskedasticity in the error terms, the Newey-West standard errors were applied. The long run estimates for the level relationships, for both models, are reported in Table 5. The error correction model associated with these long run estimates is reported in Table 6.

The negative and significant coefficient of monetary policy variable is not indicative of the trade-off between inflation variability and output volatility as suggested by Taylor (1995) but may instead be indicative of a more credible monetary policy framework in which attempts to stabilise inflation is also able to achieve more stable output growth. Results do not suggest the effectiveness of fiscal policy as a stabilization tool in the South African context. Net Capital Flows is seen to be positively related to output volatility pointing to the need for continued regulation of the balance of payment capital account. Liberalisation of trade has a positive and significant effect on output volatility which may be indicative of exposure to shocks originated from a terms-of-trade channel. For emerging markets in particular, it implies that while operating within a freely floating exchange rate system offers a certain degree of exchange rate flexibility, it may still be problematic because, regardless of the regime choice, exports, imports as well as capital flows generally constitute a relatively large share of these economies and hence they are more vulnerable to large swings in the exchange rate which in turn may lead to very substantial swings in the real economy.

The results of the equilibrium correction model reported in Table 6 below, indicates that short run dynamics between output volatility and monetary policy are also highly significant. The significant coefficient on the change in MPI seems to conform with the general consensus that shocks to the monetary policy instrument impact on output volatility with a lag. In terms of trade liberalisation, the coefficient suggests that the effects of shocks to changes in volume of trade as a percentage of GDP, still impact on output volatility after one quarter. Finally, the lagged error term is significant and both the magnitude as well as the negative sign on the coefficient is as expected since it signifies that the series converges to the long run equilibrium. Furthermore, as postulate in Bannerjee et al (1998), a highly significant coefficient, as is the case for this model, verifies the existence of a strong long-term relationship between the variables.

\section{Conclusion}

The role of this paper has been to explore trends and policy determinants of output volatility in South Africa. The results confirm that South Africa experienced a significant break in both output growth and output volatility occurring in 1991Q3, with the period after the break date characterised by lower fluctuations in output growth. Other recent and noteworthy studies in the South African context report several different structural break dates. This highlights the fact that the outcome among various studies is often sensitive to the chosen sample period, as well as the choice of methodology used to identify changes in the behaviour of the underlying series. Nevertheless the studies do not dispute the argument of moderation in output volatility in South Africa over the recent decades.

Next we set about to identify the macroeconomic policy determinants of output volatility by applying the bounds testing model. A number of implications emerge from the above results. Firstly in terms of monetary policy, the institutional commitment to attain price stability, through adopting inflation targeting, has contributed to stabilising both inflation and output. The findings in this study, coupled with the opinion that the central bank has achieved some degree of credibility, suggests that policy makers are in a position to practice monetary policy in a more prudent and flexible way that results in the stability of output without fear of creating an inflationary bias. 
With regards to net capital flows, it seems that the decision to regulate outflows of capital has largely contributed to insulating South Africa from the recent global financial crisis. In terms of trade policy, the results indicate that South Africa still faces considerable current account volatility as is evident in the increased imports volatility after the break date. This may be a consequence of the higher rand volatility suggesting that trade openness enhances the exchange rate channel, which in turn may intensify output volatility. Thus while South Africa's current monetary policy framework thrives within a floating exchange rate system, maintaining a healthy balance of the current account, which is equally important for an emerging market like South Africa, may require a more astute commitment to managing the exchange rate in order to mitigate currency volatility. Examining this link between exchange rate volatility and output volatility provides an opportunity for further research.

\section{References}

Aghion, P., Bacchetta, P. Banerjee, A. (1998). Financial Liberalization and Volatility in Emerging market Economies. Swiss National Bank, Study Centre Gerzensee. Working papers 98.02.

Agenor, P.R. McDermott, C.J. Prasad, E.S. (1999). Macroeconomic fluctuations in developing countries: Some stylised facts. IMF Working Papers 99/35, International Monetary Fund

Ahmed, S. Levin, A. Wilson, B.A. (2004). Recent US macroeconomic stability: good policies, good practices or good luck? The Review of Economics and Statistics, 86(3), 824-832

Andrews, D. W. K. (1993).Tests for parameter instability and structural change with unknown change point. Econometrica, 61, 821-856, DOI: 10.1111/1468-0262.00405, http://dx.doi.org.10.1111/1468-0262.00405

Andrews, D.W.K. and Ploberger, W. (1994). Optimal Tests when a Nuisance Parameter is Present only under the Alternative. Econometrica 62 (6), 383-1414, DOI: 10.2307/2951753, http://dx.doi.org/10.2307/2951753

Aron, J. Muellbauer, J. (2008). Transparency, Credibility and Predictability of Monetary Policy under inflation targeting in South Africa. 23rd Meeting of the European Economic Association, August 27-31, 2008, Milan Italy. (Unpublished)

Bai, J. (1997). Likelihood ratio tests for multiple structural changes. Journal of Econometrics, 91(2), 299-323,DOI: 10.1016/S0304-4076(98)00079-7, http://dx.doi.org/10.1016/S0304-4076(98)00079-7

Bai, J. Perron, P. (2003). Critical Values for Multiple Structural Change Tests. Econometrics Journal, 6, 72-78, DOI: 10.1111/1368-423X.00102, https://dx.doi.org/10.1111/1368-423X.00102

Banerjee, A. Dolado, J. Mestre, R. (1998), Error-correction mechanism tests for cointegration in single equation framework, Journal of Time Series Analysis, 19: 267-283. DOI: 10.1111/1467-9892.00091, http://dx.doi.org/10.1111/1467-9892.00091

Bejan, M. (2006).Trade openness and output volatility. MPRA Working paper 2759, University Library of Munich, Germany

Blanchard, O. Simon, J. (2001).The long and large decline in US output volatility. Brookings Papers on Economic Activity, 1, 135-164

Boivin, J. Giannoni, M.P. (2006). Has Monetary Policy become more effective? The Review of Economics and Statistics, 88(3), 445-462, DOI: 10.1162/rest.88.3.445, http://dx.doi.org/10.1162/rest.88.3.445

Burger, P.(2008). The changing Volatility of the South African Economy. South African Journal of Economics, 76(3), DOI:10.1111/j.1813-6982.2008.00198.x, http://dx.doi.org/10.1111/j.1813-6982.2008.00198.x

Cecchetti, S.G Flores-Lagunes, A. Krause, S. (2006). Assessing the sources of changes in the volatility of real growth. NBER Working Paper Number: 11946

Cecchetti, S.G. Flores-Lagunes, A. Krause, S. (2006). Has Monetary Policy become more efficient? A cross country analysis.Economic Journal, 116(115), 408-433

Cecchetti, S.G. Ehrmann, M. (1999). Does Inflation Targeting Increase Output Volatility? An International Comparison of Policymakers' Preferences and Outcomes. NBER Working Paper Number: W7426

Clarida, R. Gali, J. (2000). Monetary Policy Rules and Macroeconomic Stability: Evidence and Some Theory* Quarterly Journal of Economics, 115(1), 147-180

Du Plessis, S.A. (2006). Reconsidering the business cycle and stabilisation policies in South Africa. Economic Modelling, 23(5), 761-774

Du Plessis, S.A. Kotze, K. (2010). The great moderation of the South African Business cycle. Economic History of Developing Regions, 25(1), 105-125 
Du Plessis, S.A. Smit, B.W. Sturzenegger, F. (2007). The Cyclicality of Monetary and Fiscal Policy in South Africa since 1994. South African Journal of Economics, 75(3), 391-411, DOI: 10.1111/j.1813-6982.2007.00128.x, http://dx.doi.org/10.1111/j.1813-6982.2007.00128.x

Du Toit, L. (2008). Optimal HP filtering for South Africa. Stellenbosch Working Paper Series No. WP07/2008.

Easterly, W., Islam, R. and Stiglitz, J.E. (2001). Shaken and Stirred: Explaining growth volatility. Annual World bank Conference

Fatas, A. and Mihov, I. (2001). The macroeconomic effects of fiscal policy rules in the United States. Journal of Public economics, 90(1-2), 101-117

Gali J and Gambetti L. (2009). On the Sources of the great moderation. American Economic Journal: Macroeconomic, DOI:10.1257//mac.1.1.26, http://dx.doi.org/10.1257//mac.1.1.26

Gujarati, D.N. (1995). Basic Econometrics. (3 ${ }^{\text {rd }}$ ed), McGraw Hill, (Chapter 21)

Hakura, D. (2007).Output Volatility and large output drops in Emerging market and developing countries. IMF Working Paper no 07/114.

Hansen, B.E. (1997). Approximate Asymptotic P Values for Structural-Change Tests. Journal of Business and Economic Statistics, 15(1), 60-67, DOI: 10.2307/1392074, http://dx.doi.org/10.2307/1392074

Hodrick, R.J. Prescott, E.C. (1980). Post-war US Business Cycles: An Empirical Investigation. Discussion Paper 451, Pittsburgh: Carnegie-Mellon University

Kahn, J. McConnell, M.M. Perez-Quiros, G. (2001). Inventories and the information revolution: implications for output volatility. Federal Reserve Bank of New York Working Paper

Kent, C. Smith, K. Holloway, J. (2005). Declining Output Volatility: What Role for Structural Change? RBA Research Discussion Paper No. rdp 2005-08

Kose, M.A. Prasad, E.S. Terrones, M.E. (2006). How does Trade and Financial Integration affect the relationship between growth and volatility? Journal of International Economics, 69(1), 176-202

Krugman, P. (1993). Lessons of Massachusetts for EMU. In The Transition to Economic and Monetary Union in Europe, ed. by F. Giavazzi and F. Torres, Cambridge: Cambridge University Press, 241-261,DOI:10.1017/CB09780511599231.016, http://dx.doi.org.10.1017/CB09780511599231.016

Malik, A. Temple, J. R.W. (2009). The geography of output volatility. Journal of Development Economics, 90 (2), 163-178. DOI:10.1016/j.jdeveco.2008.10.003, http:dx.doi.org/10.1016/j/jdeveco.2008.10.003

McConnell, M.M, Perez-Quiros, G. (2000). Output Fluctuations in the United States: what has changed since the early1980's?AmericanEconomicReview,90(5),1464-1476,DOI:10.1257/aer.90.5.1.1464,http://dx.doi.org/10.1257/aer 90.5.1464

Mills, T.C. Wang, P. (2000). Searching for the sources of stabilisation in output growth areas: evidence from the G7 economies. Loughborough University, Research Paper No. 00/7.

Pesaran, H. Shin, Y. (1995). An Autoregressive distributed lag approach to cointegration. University of Cambridge, working paper no 9514, 10.1017/CCOL0521633230.011, http://dx.doi.org/10.1017/CCOL0521633230.011

Pesaran, H. Shin, Y. Smith, R.J. (2001). Bounds Testing approaches to the Analysis of Level Relationships. Journal of Applied Econometrics, 16, 289-326, DOI: 10.1002/jae.616, http://dx.doi.org/10.1002/jae.616

Pretorius, W.S. Venter, J.C. (2001). A note on business cycles in South Africa during the period 1997 to 1999. Quarterly Bulletin, South African Reserve Bank.

Pretorius, W.S. Venter, J.C. Wiedeman, P.J. (1999). Business cycles in South Africa during the period 1993 to 1997.Quarterly Bulletin, South African Reserve Bank

Ramey, G. Ramey, V.A. (2000). Cross Country Evidence on the link between Volatility and Growth. American Economic Review, 85(5), 1138-1151

Razin, A. Rose, A.K. (1991). Business-cycle volatility and openness: an exploratory cross-sectional analysis. NBER Working Paper No. 4208, National Bureau of Economic Research

Smith, P. Summers, P.M. (2002). Regime Switches in GDP Growth and Volatility: Some International Evidence and Implications for Modelling Business Cycles. wp2002n21, Melbourne Institute of Applied Economic and Social Research, The University of Melbourne DOI:10.2202/1935-1690.1741, http://dx.doi.org/10.2202/1935-1690.1741 
Stock, J.H. Watson, M.W.(2002). Has Business cycle Volatility changed and why? NBER Macroeconomics Annual, 17, 159-218.

Svensson, L.E.O.(2000).Open-Economy inflation targeting. Journal of international Economics, 50, 153-183, DOI: 10.2139/ssrn.30745,http://dx.doi.org/10.2139/ssrn.30745

Svensson, L.E.O. Hall, F. (2003). Monetary policy and real stabilisation. NBER Working Paper No. 9486, National Bureau of Economic Research.

Taylor, J.B. (1995). The Inflation/output trade-off revisited. In: Goals, Guidelines, and Constraints Facing Monetary Policymakers.

. (1993). Discretion versus policy rules in practice. Carnegie-Rochester Conference Series on public policy, DOI:10.1016,0167/2231(93)90009-L, http://dx.doi.org/10.1016/0167-2231(93)90009-L

Van den Noord, P. (2000). The size and Role of Automatic Stabilizers in the 1990's and beyond. OECD Economics Department Working Paper No. 230

Wolf, H. (2004). Volatility: Definitions and Consequences. World Bank Draft Chapter for Managing Volatility and Crisis: $\quad$ A $\quad$ Practitioner's $\quad$ Guide. $\quad$ DOI: $\quad 10.1017 /$ CB9780511510755.004, http://dx.doi.org/10.1017/CBO9780511510755.004

Woodford, M. (2001). The Taylor-Rule and Optimal Monetary Policy. The American Economic Review, 91(2), Papers and Proceedings of the Hundred Thirteenth Annual Meeting of the American Economic Association, pg 232-237, DOI: 10.1257/aer.91.2.232, http://dx.doi.org/10.1257/aer.91.2.232

Table 1. Structural break test of AR(1) coefficients: GDP Growth and GDP Volatility :1970Q4 2010Q3

\begin{tabular}{|c|c|c|c|c|c|c|c|c|c|}
\hline \multicolumn{4}{|c|}{ GDP Growth } & \multicolumn{6}{|c|}{ GDP Growth Volatility } \\
\hline \multicolumn{4}{|c|}{$\begin{array}{l}\text { Structural break test in AR(1) } \\
\text { coefficients: GDP Growth-1970Q4 2010Q3 }\end{array}$} & \multicolumn{6}{|c|}{ Residual variance break tests on AR(1): GDP Growth- 1970Q4-2010Q3, (Trimmed } \\
\hline \multirow{2}{*}{\multicolumn{4}{|c|}{ Model: $\Delta y=\mu+\rho \Delta y_{t-1}+\varepsilon_{t}$}} & \multicolumn{6}{|c|}{ Model: $\sqrt{ } \Pi / 2|\varepsilon \tau|=\alpha+\mu \tau$} \\
\hline & & & & \multicolumn{3}{|c|}{ 1976Q4 2004Q2 } & \multicolumn{3}{|c|}{ 1982Q2 1997Q4 } \\
\hline $\begin{array}{l}\text { Null } \\
\text { Hypothesis }\end{array}$ & Sup LR & Exp LR & Ave LR & Sup LR & Exp LR & Ave LR & Sup LR & Exp LR & Ave LR \\
\hline$\mu_{1}=\mu_{2}$ & 8.5887 & 3.44616 & 5.9192 & 8.30029 & 2.52045 & 8.16612 & 8.16612 & 3.19172 & 5.50003 \\
\hline$\rho_{1}=\rho_{2}$ & $(0.028)$ & $(0.007)$ & $(0.005)$ & $(0.365)$ & $(0.245)$ & $(0.034)$ & $(0.034)$ & $(0.011)$ & $(0.008)$ \\
\hline \multicolumn{4}{|c|}{ Break Date: 1991Q3 } & \multicolumn{3}{|c|}{ Break Date: None } & \multicolumn{3}{|c|}{ Break Date: 1991Q3 } \\
\hline
\end{tabular}

Table 2. The Standard Deviation of Real GDP and its components

\begin{tabular}{|c|c|c|}
\hline Variable & Period $1[1970 \mathrm{Q} 1-1991 \mathrm{Q} 3]$ & Period 2[1991Q4-2010Q3] \\
\hline Real GDP & 6.257737 & 2.210894 \\
\hline $\mathrm{C}$ & 2.940790 & 1.064852 \\
\hline $\mathrm{I}$ & 3.627817 & 2.511113 \\
\hline $\mathrm{G}$ & 3.243398 & 2.541293 \\
\hline $\mathrm{X}$ & 4.067417 & 3.960700 \\
\hline $\mathrm{M}$ & 3.735690 & 5.532232 \\
\hline
\end{tabular}

Source: Authors Calculations using data available from the SARB. Where $\mathrm{C}=$ Consumption Expenditure by Households, I= Private Investment. $\mathrm{G}=$ Government Expenditure, $\mathrm{X}=$ Exports and $\mathrm{M}=$ Imports as proportions of GDP. 
Table 3. Augmented Dickey Fuller Tests for Unit Roots

\begin{tabular}{|c|c|c|c|}
\hline Variable & $\begin{array}{l}\text { Test Critical } \\
\text { Value(1\% Level) }\end{array}$ & $\begin{array}{l}\text { Computed } \\
\text { T-Statistic }\end{array}$ & $\begin{array}{l}\text { Probability } \\
\text { T-Statistic }\end{array}$ \\
\hline GDPVOL & -3.470934 & -20.84152 & 0.0000 \\
\hline First Difference of GDPVOL & -3.471192 & $-26.12191=$ & 0.0000 \\
\hline Monetary Policy Indicator (MPI) & -3.489117 & -10.53938 & 0.0000 \\
\hline First Difference MPI & -3.489659 & -13.63427 & 0.0000 \\
\hline Fiscal Policy Indicator(FPI) & -3.470934 & $-10.01610^{2}$ & 0.0000 \\
\hline First Difference of FPI & -3.470934 & -27.40131 & 0.000 \\
\hline Net Capital Flows(NCF) & -3.470934 & -4.818577 & 0.0001 \\
\hline First Difference of NCF & -3.470934 & -15.98684 & 0.0000 \\
\hline Trade Liberalisation Indicator (TRADEOPEN) & -3.470934 & -2.670073 & 0.0815 \\
\hline
\end{tabular}

Note: If the absolute value of the computed absolute value of the t-statistic, exceeds the ADF absolute critical values, we can reject the hypothesis of a unit root: Gujarati (1993), *** denotes significance at the $1 \%$ level

Table 4. Statistics for selecting the appropriate lag order of the output volatility equation

\begin{tabular}{|l|l|l|l|l|}
\hline \multicolumn{5}{|l|}{ With Deterministic Trend ind intercept } \\
\hline$\rho$ & AIC & SBC & $\chi 2 \operatorname{sc}(1)$ & $\chi 2 \operatorname{sc}(4)$ \\
\hline 1 & 5.113739 & 5.502096 & 0.002144 & $4.219974^{* * *}$ \\
\hline 2 & 5.123546 & 5.536175 & 0.144331 & $6.252487 * * *$ \\
\hline 3 & 5.111151 & 5.548053 & $2.593088^{*}$ & $5.085537^{* * *}$ \\
\hline 4 & 4.991167 & 5.452340 & 0.194818 & $5.802186^{* * *}$ \\
\hline 5 & 5.007785 & 5.493231 & 0.681133 & $6.045650^{* * *}$ \\
\hline 6 & 5.007629 & 5.517348 & 0.018261 & $6.280401 * * *$ \\
\hline
\end{tabular}

Note: $\mathrm{p}$ is the lag order of the underlying variables for the conditional ECM (2), with zero restrictions on the coefficients of lagged changes in policy variables. . AICp $=\mathrm{LLp} \_$sp and SBCp $=\mathrm{LLp}-(\mathrm{sp} / 2) \ln \mathrm{T}$ denote

Akaike's and Schwarz's Bayesian Information Criteria for a given lag order $\mathrm{p}$, where LLp is the maximized log-likelihood value of the model, sp is the number of freely estimated coefficients and $\mathrm{T}$ is the sample size.

$\chi 2 \operatorname{sc}(1)$ and $\chi 2 \operatorname{sc}(4)$ are the LM statistics for testing no residual serial correlation against orders 1 and 4.

* and **; denotes significance at the $1 \%$ and $5 \%$ levels respectively.

Table 5. Estimated Long Run Coefficients: Model with Intercept and Deterministic Trend

\begin{tabular}{|l|l|l|l|l|}
\hline \multicolumn{2}{|l|}{ Equation (3): ARDL(3,3,0,0,1) selected based on AIC criterion. Dependent variable is $\boldsymbol{\sigma}_{\mathbf{y}}$} \\
\hline Method: Least Squares, Newey-West HAC Standard Errors \& Covariance (lag truncation=4) \\
\hline \\
Regressors & Coefficient & Standard Errors & T-Statistic & $\begin{array}{l}\text { Probability on } \\
\text { T-Statistic }\end{array}$ \\
\hline GDPVOL(-1)* & -0.340294 & 0.103782 & -3.278943 & 0.0014 \\
\hline MPI* & -0.000947 & 0.000124 & -7.613198 & 0.0000 \\
\hline FPI & -0.038267 & 0.127689 & -0.299686 & 0.7651 \\
\hline NCF & 40.79993 & 35.78601 & 1.140108 & 0.2570 \\
\hline TRADEOPEN** & 0.159866 & 0.080875 & 1.976693 & 0.0509 \\
\hline C & 143.8937 & 176.5990 & 0.814804 & 0.4172 \\
\hline TT & -0.071734 & 0.087971 & -0.815431 & 0.4168 \\
\hline ITDUMMY & 0.557914 & 0.827338 & 0.674348 & 0.5017 \\
\hline
\end{tabular}

Source: Authors calculations. $* * * *$ and $* * *$ denote significance at $1 \%, 5 \%$ and $10 \%$ levels respectively

R-squared $=0.243$ Adjusted R-squared $=0.1416$, S.E. of regression=2.826; Akaike info criterion= 5.033, Schwarz criterion=5.3748 Durbin-Watson stat $=2.16$ 
Table 6. ECM ARDL (3,3,0,0,1) volatility equation

Model with Intercept, Deterministic Trend and Seasonal Dummy Variables

\begin{tabular}{|l|l|l|l|l|}
\hline \multicolumn{2}{|l|}{ ARDL (3,3,0,0,1) selected based on AIC. Dependent Variable $\Delta \boldsymbol{\sigma}_{\mathbf{y}}$} \\
\hline \multicolumn{2}{|l}{ Method: Least Squares, Newey-West HAC Standard Errors \& Covariance (lag truncation=4) } \\
\hline Regressors & Coefficients & $\begin{array}{l}\text { Standard } \\
\text { Errors }\end{array}$ & T-Statistic & $\begin{array}{l}\text { Probability on } \\
\text { T-Statistic }\end{array}$ \\
\hline$\Delta \sigma_{\mathrm{yt}}$ & 1.000000 & $1.47 \mathrm{E}-16$ & $6.78 \mathrm{E}+15$ & 0.0000 \\
\hline$\Delta \sigma_{\mathrm{yt}-1}$ & $1.79 \mathrm{E}-15$ & $2.33 \mathrm{E}-16$ & 7.691127 & 0.0000 \\
\hline$\Delta \sigma_{\mathrm{yt}-2}$ & $1.42 \mathrm{E}-16$ & 6.334029 & 0.0000 \\
\hline$\Delta \mathrm{MPI}$ & $9.02 \mathrm{E}-16$ & $1.14 \mathrm{E}-18$ & -2.203527 & 0.0299 \\
\hline$\Delta \mathrm{MPI}_{\mathrm{t}-1}$ & $-2.51 \mathrm{E}-18$ & $1.29 \mathrm{E}-18$ & -0.769122 & 0.4437 \\
\hline$\Delta \mathrm{MPI}_{\mathrm{t}-2}$ & $-9.89 \mathrm{E}-19$ & $1.15 \mathrm{E}-18$ & -0.918935 & 0.3604 \\
\hline$\Delta \mathrm{FPI}$ & $-1.05 \mathrm{E}-18$ & $1.19 \mathrm{E}-16$ & 0.002351 & 0.9981 \\
\hline$\Delta \mathrm{NCF}$ & $2.79 \mathrm{E}-19$ & $6.49 \mathrm{E}-14$ & 1.216957 & 0.2265 \\
\hline$\Delta \mathrm{TRADE}$ & $7.90 \mathrm{E}-14$ & $1.03 \mathrm{E}-16$ & 4.210837 & 0.0001 \\
\hline Intercept & $4.32 \mathrm{E}-16$ & $1.95 \mathrm{E}-13$ & -0.927768 & 0.3558 \\
\hline Trend & $-1.81 \mathrm{E}-13$ & $9.90 \mathrm{E}-17$ & -1.640875 & 0.1040 \\
\hline ITDUMMY & $-1.62 \mathrm{E}-16$ & $1.59 \mathrm{E}-15$ & 0.421629 & 0.6742 \\
\hline$v_{\mathrm{ECM}}(-1)$ & $6.69 \mathrm{E}-16$ & $3.78 \mathrm{E}-16$ & -9.387335 & 0.0000 \\
\hline
\end{tabular}

$v_{\mathrm{ECM}}=\sigma_{\mathrm{y}}+0.0009 * \mathrm{MPI}+0.038267 * \mathrm{FPI}-40.79993 * \mathrm{NCF}-0.159866 *$ TRADEOPEN $-143.8967 * \mathrm{C}$

$* ; * *$ and $* * *$ denote significance at the $1 \%, 5 \%$ and $10 \%$ levels respectively

R-squared=1,0000 Adjusted R-squared=1,0000, S.E. of regression=4,989683;Durbin-Watson stat=1,223020

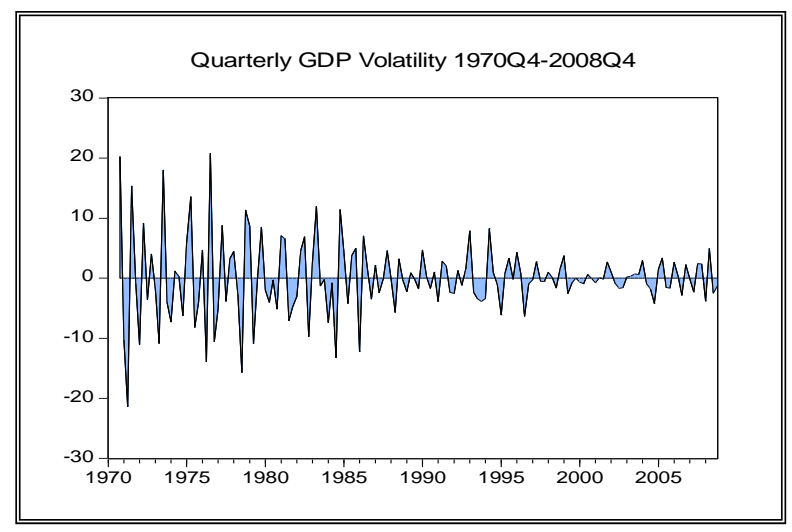

Source: Authors calculation using data obtained from the South African Reserve Bank (SARB) online data facility. Volatility is measured as the deviation of quarterly GDP growth from an HP filter.

Figure 1. Quarterly GDP Growth Volatility 